\section{JURNAL PENELITIAN PENDIDIKAN IPA}

http://jurnal.unram.ac.id/index.php/jpp-ipa
e-ISSN : 2407-795X

p-ISSN : 2460-2582

Vol 2, No, 1

Januari 2016

\title{
PERBANDINGAN KINERJA ALGORITMA PROMETHEE DAN TOPSIS UNTUK PEMILIHAN GURU TELADAN
}

\author{
Bayu Firmanto ${ }^{1}$, Harry Soekotjo ${ }^{2}$ Dachlan, Hadi Suyono ${ }^{3}$ \\ Program Studi Magister Teknik Elektro, Jurusan Teknik Elektro, Fakultas Teknik, Universitas \\ Brawijaya Malang ${ }^{123}$
}

Email: bayufirmanto@gmail.com

\begin{abstract}
Key Words
Calon guru

teladan,

sistem

pendukung

keputusan,

metode

PROMETHE

EE, dan

metode

TOPSIS.

Abstract

Department of Education has a mission to improve the quality of education by conducting quality improvement programs in aspects of facilities/infrastructure, curriculum, and the availability of qualified teachers. By conducting an exemplary teacher assessment, which aims to provide incentives to teachers to excel in the field of competence.Based on the he survey taken from City Education Department states that exemplary teacher assessment is currently done manually. Decision Support System is expected to improve performance and simplify the process of selection of candidates. In this study, the data exemplary teacher candidate selection used includes teacher data repot that contains the marks of the orientation of services, integrity, commitment, discipline, cooperation, leadership, performance and behavior. The proposed methods to solve the the exemplary teacher selection are PROMETHEE and TOPSIS methods.Based on the test performed showed that, the precision, recall, and accuracy parameter of the selection of the exemplary teacher candidates, have been produced $91.19 \%, 54.31 \%$ and $88.41 \%$ respectively for PROMETHEE method, and have been resulted $90.50 \% 74.91 \%$ and $94.34 \%$ respectively, for TOPSIS method. Therefore, the TOPSIS method has a better performance compared with the PROMETHEE method.
\end{abstract}

\begin{tabular}{|c|c|}
\hline Kata Kunci & Abstrak \\
\hline $\begin{array}{l}\text { Prospective } \\
\text { teacher role } \\
\text { models, } \\
\text { decision } \\
\text { support } \\
\text { systems, } \\
\text { PROMETH } \\
\text { EE, and } \\
\text { TOPSIS }\end{array}$ & $\begin{array}{l}\text { Dinas Pendidikan Kota memiliki misi meningkatkan mutu pendidikan dengan melakukan } \\
\text { program-program peningkatan mutu dalam aspek sarana/prasarana, kurikulum, dan } \\
\text { ketersediaan guru berkualitas. Dengan mengadakan penilaian guru teladan yang bertujuan } \\
\text { untuk memberikan dorongan agar para guru untuk berprestasi dalam bidang kompetensi. } \\
\text { Survey yang diambil dari Dinas Pendidikan Kota menyatakan bahwa penilaian guru } \\
\text { teladan saat ini dilakukan dengan cara manual. Sistem Pendukung Keputusan diharapkan } \\
\text { mampu meningkatkan kinerja dan mempermudah proses seleksi penerima beasiswa. Pada } \\
\text { penelitian ini, data pemilihan calon guru teladan yang digunakan meliputi data rapot guru } \\
\text { yang berisi nilai orientasi pelayan, integritas, komitmnen, disiplin, kerjasama, } \\
\text { kepemimpinan, prilaku kerja dan ahlaq. Metode yang diusulkan dalam menyelesaikan } \\
\text { masalah pemilihan guru teladan ini adalah metode Prometheee dan TOPSIS. Hasil } \\
\text { pengujian sistem menunjukkan bahwa pemilihan calon guru teladan menghasilkan nilai } \\
\text { precision, recall, dan accuracy untuk metode PROMETHEEmasing-masing adalah } \\
\text { 91,19\%,54.31\%, dan } 88.41 \% \text {, dan 90.50\%,74.91\% dan 94.34\% untuk metode TOPSIS. } \\
\text { Sehingga dengan demikian, metode TOPSIS memiliki unjuk kerja yang lebih baik } \\
\text { dibandingkan dengan metode PROMETHEE }\end{array}$ \\
\hline
\end{tabular}




\section{PENDAHULUAN}

Dinas Pendidikan Kota memiliki misi meningkatkan mutu pendidikan dengan melakukan program-program peningkatan mutu dalam aspek sarana/prasarana, kurikulum, dan ketersediaan guru berkualitas. Metode peningkatan kualitas guru dilakukan dengan pengadaan kegiatan workshop, penelitian, dan pemilihan guru teladan. Dinas Pendidikan harus terus memastikan bahwa kriteria-kriteria tersebut bisa dipenuhi untuk mewujudkan kualitas pendidikan dan pengajaran yang lebih baik. Untuk bisa mengetahui apakah seorang guru berkualitas, salah satu metode yang bisa dilakukan adalah dengan melacak prestasi yang telah diraih.

Prestasi guru dipandang sebagai metode tangible dalam mengetahui seberapa kompeten guru yang dinilai. Dengan pemahaman tersebut, Pemerintah Kota melalui Dinas Pendidikan Kota meningkatkan kompetensi guru di wilayah Kota dengan melakukan beberapa cara, salah satunya adalah dengan mengadakan penilaian guru teladan yang bertujuan untuk memberikan dorongan agar para guru untuk berprestasi dalam bidang kompetensinya. Berdasarkan survey yang diambil dari Dinas Pendidikan Kota menyatakan bahwa penilaian guru teladan saat ini dilakukan dengan cara manual.
Cara manual tersebut dilakukan dari proses pemberkasan hingga proses pengurutan nilai dari masing-masing kompetensi sebelum akhirnya pemilihan tiga guru teladan Kota dilakukan berdasarkan dari nilai tertinggi dari tiap indikator kompetensi. Namun dalam proses penilaian yang selama ini dilakukan terdapat faktorfaktor subyektif yang menghambat proses penilaian.

Disamping itu, berdasarkan survey yang diambil dari guru, faktor subyektif berupa pemilihan guru di sekolah yang ditunjuk langsung oleh kepala sekolah terkadang tanpa berdasarkan alasan yang rasional dan juga kadang menimbulkan berbagai pertanyaan dikalangan guru. Kendala lain dari pemilihan guru teladan ini juga adalah proses penilaian yang dilakukan juga memerlukan waktu yang lama dan tidak efektif, banyaknya pengumpulan berkas calon yang melampaui batas waktu, dan tidak semua sekolah dapat berpartisipasi dalam mengikuti proses seleksi guru teladan.

Sistem pendukung keputusan (SPK) adalah suatu sistem yang dapat membantu menentukan suatu keputusan dengan cara pengolahan kriteria-kriteria yang telah ditetapkan secara terstruktur. Menurut Kusumadewi (2006), terdapat beberapa metode dalam sistem pendukung keputusan 
seperti: AHP (Analitical Heurarchy Process), Promethee, TOPSIS (Technique Order Preference by Similarity to Ideal Solution), Electree dan Profile-matching.

Metode Promethee termasuk dalam keluarga metode outranking yang dikembangkan dan meliputi dua tahap yaitu: membangun hubungan outranking kemudian mengeksploitasi hubungan outranking tersebut untuk mendapatkan jawaban atas optimasi kriteria (Vincke, 1986). Pada tahap pertama nilai hubungan outranking dibuat berdasarkan pertimbangan dominasi masing masing kriteria. Pada tahap ini, indeks preferensi ditentukan dan grafik nilai outranking dibuat untuk menunjukkan preferensi pembuat keputusan. Pada tahap kedua, eksploitasi dilakukan dengan mempertimbangkan nilai leaving flow dan entering flow pada grafik nilai outrankingberupa urutan parsial untuk Promethee I dan urutan lengkap untuk Promethee II (Novaliendry, 2009). Metode Promethee dipilih karena sebetulnya metode ini memiliki keunggulan berupa kemampuan untuk melakukan perbandingan antarsesama elemen secara individual. Hal ini artinya Promethee mampu membandingkan satu calon guru dengan calon guru lainnya satu persatu, sehingga tingkat presisi menjadi lebih baik, dibandingkan denganmetode lainnya yangmelakukan perbandingansecara kolom dan kebanyakan prosesnya lainya melakukan perbandingansecara grup.

Hasil perhitungan dari algoritma tersebut akan dibandingkan dengan metode AHP-TOPSIS untuk perbandingan unjuk kinerja.TOPSIS tidak hanya memiliki waktu eksekusi yang lebih cepat daripada metode-metode yang lain namun juga memiliki konsep yang sederhana. Namun demikian proses penentuan seleksi guru teladan memerlukan pemilihan yang dilakukan secara manual dan dilakukan oleh Dinas Pendidikan.

\section{LANDASAN TEORI}

\section{A. Sistem Pendukung Keputusan}

Sistem Pendukung Keputusan (SPK), adalah suatu "situasi dimana sistem 'final' dapat dikembangkan hanya melalui adaptive process pembelajaran dan evolusi." SPK didefinisikan sebagai hasil dari pengembangan proses dimana user SPK, SPK builder, dan SPK itu sendiri, semuanya bisa saling mempengaruhi, dan tercermin pada evolusi sistem itu dan polapola yang digunakan (Sprague, et al, 1989).

\section{B. Algoritma Promethee}

Promethee adalah suatu metode penentuan urutan (prioritas) dalam MCDM. Fitur utama metode ini adalah kesederhanaan, kejelasan, dan kestabilan. 
Dugaan dari dominasi kriteria yang digunakan dalam Promethee adalah penggunaan nilai dalam hubungan outranking. Dalam Promethee terdapat enam bentuk fungsi preferensi kriteria. Meskipun tidak bersifat mutlak, bentukbentuk ini cukup baik untuk beberapa kasus. Dalam penelitian ini bentuk preferensi yang diambil adalah preferensi linear. Preferensi linear dipilih karena tipe data yang digunakan cocok dengan preferensi ini (Vincke, 1986). Sementara itu, untuk memberikan gambaran yang lebih baik terhadap area yang tidak sama, digunakan fungsi selisih nilai kriteria antara alternatif $H(d)$, yang mempunyai hubungan langsung dengan fungsi preferensi:

$\left.\begin{array}{c}A a, b \in a \\ f(a), f(b)\end{array}\right\} f a(a)>f(a) \leftrightarrow a \operatorname{Pb} f(a) \leftrightarrow a I b(1)$

dengan

$A a=$ Outrangking.

$b, a=$ anggota suatu area.

$f(a), f(b)=$ fungsi a dan fungsi $b$.

$a P b f(a)=$ selisih preferensi kriteria alternatif.

$a I b=$ selisih nilai kriteria alternatif.

Secara umum peran kingan yang dilakukan dengan metode Promethee meliputi tiga bentuk yaitu:

\section{1) Menetukan entering flow}

Entering flow adalah jumlah dari yang memiliki arah mendekat dari node a dan hal ini merupakan karakter pengukuran outranking. Setiap nilai node a dalam grafik

nilai outranking ditentukan berdasarkan entering flow dengan persamaan:

$$
\emptyset^{+}(a 1)=\sum_{i=1}^{I} \pi\left(a 1^{\prime}, a i\right)
$$

dengan:

$\emptyset^{+}=$entering flow

$\pi=$ nilai total prefensi

$a=$ nilai outranking

$i=$ jumlah obyek seleksi

2) Menetukan leaving flow dengan persamaannya:

$$
\emptyset^{-}(a 1)=\sum_{i=1}^{I} \pi\left(a 1, a i^{\prime}\right)
$$

dengan:

$\emptyset^{-}=$leaving flow.

$\pi=$ nilai total prefensi.

$a=$ nilai outranking.

$i=$ jumlah obyek seleksi.

3) Penentuan nilai net flow

Semakin besar nilai entering flow dan semakin kecilleaving flow maka alternatif tersebut memiliki kemungkinan dipilih yang semakin besar. Persamaannya sebagai berikut:

$$
\emptyset(a 1)=\emptyset^{+}(a 1)-\emptyset^{-}(a 1)
$$

dengan:

$\emptyset^{+}=$entering flow.

$\emptyset^{-}=$leaving flow.

$\varnothing=$ net flow.

Perankingan dalam Promethee I dilakukan secara parsial, yaitu didasarkan pada nilai entering flow dan leaving flow.Sedangkan Promethee II 
termasuk dalam perankingan komplek karena didasarkan pada nilai net flow masing-masing alternatif, yaitu alternatif dengan nilai net flow lebih tinggi menempati suatu ranking yang lebih baik.Pada penelitian ini, Algoritma Promethee yang digunakan adalah Algoritma Promethee II.

\section{Algoritma TOPSIS}

TOPSIS adalah salah satu metode pengambilan keputusan multikriteria yang pertama kali diperkenalkan oleh Yoon dan Hwang dan merupakan pengembangan dari metode AHP (Kahraman, 2008). Prinsip metode TOPSIS sederhana yaitu bahwa alternatif terpilih yang terbaik tidak hanya memiliki jarak terpendek dari solusi ideal positif, namun juga memiliki jarak terpanjang dari solusi ideal negatif.Solusi ideal positif didefinisikan sebagai jumlah dari seluruh nilai terbaik yang dapat dicapai untuk setiap atribut, sedangkan solusi negatif-ideal terdiri dari seluruh nilai terburuk yang dicapai untuk setiap atribut. Jarak menuju masing-masing kutub kinerja diukur. Menurut Hwang (1993) (Kusumadewi, 2006) dalam konsep ini banyak digunakan pada beberapa model MADM untuk menyelesaikan masalah keputusan secara praktis.
Secara garis besar prosedur TOPSIS terdiri dari langkah-langkah sebagai berikut:

1) Menentukan matriks keputusan yang ternormalisasi:

Kriteria untuk pemilihan guru teladan dibutuhkan oleh TOPSIS untuk membuat matriks ternomalisasi.

Matriks ternormalisasi dapat dituliskan dengan persamaan berikut:

$$
r_{i j}=\frac{x_{i j}}{\sqrt{\sum_{i=1}^{m} x_{i j}^{2}}}
$$

dengan :

$r_{i j}=$ Normalisasi matrik

$x_{i j}=$ Nilai data pada baris ke $i$ dan kolom ke $j$

$\sum_{i=1}^{m} x_{i j}^{2}=$ Akar kuadrat dari jumlah baris ke $i$ kolom ke $j$

$i=$ alternatif ke $i$

$j=$ kriteria ke $j$

2) Menghitung matriks keputusan yang ternormalisasi terbobot:

Persamaan (6) digunakan untuk menghitung matriks ternormalisasi terbobot dan persamaan (7) untuk menghitung perkalian bobot dengan matriks ternormalisasi.

$$
\begin{aligned}
& \mathrm{w}=w_{1}, w_{2}, w_{3}, \ldots ., w_{n} \\
& y_{i j}=w_{i} . r_{i j}
\end{aligned}
$$

dengan:

$$
\begin{aligned}
& \mathrm{w}=\text { bobot prioritas } \\
& y_{i j}=\text { matrik ternormalisasi terbobot }
\end{aligned}
$$


$w_{i}=$ bobot prioritas ke $i$

$r_{i j}=$ matriks ternormalisasi

3) Menghitung matriks solusi ideal positif dan matriks solusi negatif:

Solusi ideal positif dan solusi ideal negatif dapat ditentukan berdasarkan rating bobot ternormalisasi.

$A^{+}=\left(y_{1}^{+}, y_{2}, \ldots y_{m}\right) \& A^{-}=$

$\left(y_{1}^{-}, y_{2}, \ldots y_{m}\right)$

dengan :

$A^{+}=$solusi ideal positif, $A^{-}=$solusi ideal negatif

$y_{i j}^{+}$adalah:

$-\min y_{i j}$, jika $j$ adalah atribut biaya (cost)

$-\max y_{i j}$, jika $j$ adalah atribut keuntungan

$y_{i j}^{-}$adalah:

- max $y_{i j}$, jika $j$ adalah atribut keuntungan

$-\min y_{i j}$, jika $j$ adalah atribut biaya (cost)

Menghitung jarak antara nilai setiap alternatif dengan matriks solusi ideal positif dan matriks solusi ideal negatif:

Jarak alternatif $\left(D_{i}^{+}\right)$dengan solusi ideal positif:

$D_{i}^{+}=\sqrt{\sum_{i-1}^{n}\left(y_{i j}-y_{i}^{+}\right)^{2}}$

Jarak alternatif $\left(D_{i}^{-}\right)$dengansolusi ideal negatif :

$D_{i}^{-}=\sqrt{\sum_{i-1}^{n}\left(y_{i j}-y_{i}^{-}\right)^{2}}$

4) Menghitung nilai preferensi untuk setiap alternative.
Persamaan untuk menghitung nilai preferensi ditampilkan pada persamaan berikut:

$$
V_{i}=\frac{D_{1}^{-}}{D_{1}^{-}+D_{1}^{+}}
$$

dengan :

$$
\begin{aligned}
& V_{i}=\text { nilai preferensi } \\
& D_{1}^{-}=\text {jarak antar solusi ideal negatif } \\
& D_{1}^{+}=\text {jarak antar solusi ideal positif }
\end{aligned}
$$

5) Melakukan alternatif perangkingan

Alternatif dapat diranking
berdasarkan urutan $V_{i}$. Maka dari itu, alternatif terbaik adalah salah suatu alternatif yang berjarak terpendek dari solusi ideal, dan berjarak terjauh dari solusi negatif-ideal, yaitu alternatif yang memiliki nilai preferensi tertinggi.Dari hasil perhitungan di atas dapat diketahui beberapa alternatif guru yang layak sebagai guru teladan.

\section{METODE PENELITIAN}

\section{Konsep Algoritma}

Konsep alur penelitian ini dapat diuraikan sebagai berikut:

\section{a. Algoritma Promethee}

Langkah-langkah perhitungan dengan metode Promethee adalah sebagai berikut:

1) Menentukan beberapa alternatif,

2) Menentukan beberapa dan dominasi kriteria. 
3) Menentukan tipe penilaian, dimana tipe penilaian memiliki dua tipe: minimum dan maksimum.

4) Menentukan tipe preferensi untuk setiap kriteria yang paling cocok didasarkan pada data dan pertimbangan dari decision maker. Tipe preferensi ini berjumlah enam (Usual, Quasi, Linear, Level, Linear Quasi, dan Gaussian).

5) Memberikan

nilai threshold atau kecenderungan untuk setiap kriteria berdasarkan preferensi yang telah dipilih.

6) Perhitungan entering danleaving flow dan net flow.

7) Pengurutan hasil dari perankingan.

Algoritma Promethee dapat dilihat pada Gambar 1.

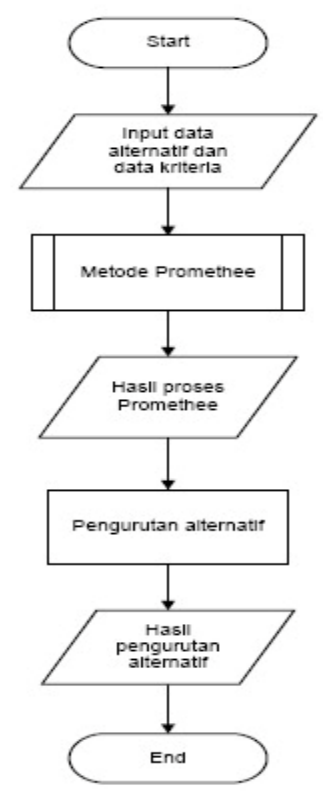

Gbr.1 Flowchart Algoritma Promethee

b. Algoritma TOPSIS
Langkah perhitungan TOPSIS dapat dilihat pada Gambar 2. Pada proses tersebut, input data guru yang dilakukan menentukan matriks keputusan yang ternormalisasi. Dari matriks tersebut, diperoleh bobot yang dapat menentukan matriks solusi ideal positif dan matriks solusi ideal negatif.Dari jarak antar nilai matriks solusi tersebut, dapat ditentukan preferensi untuk setiap alternatif dan kemudian dilakukan perankingan.

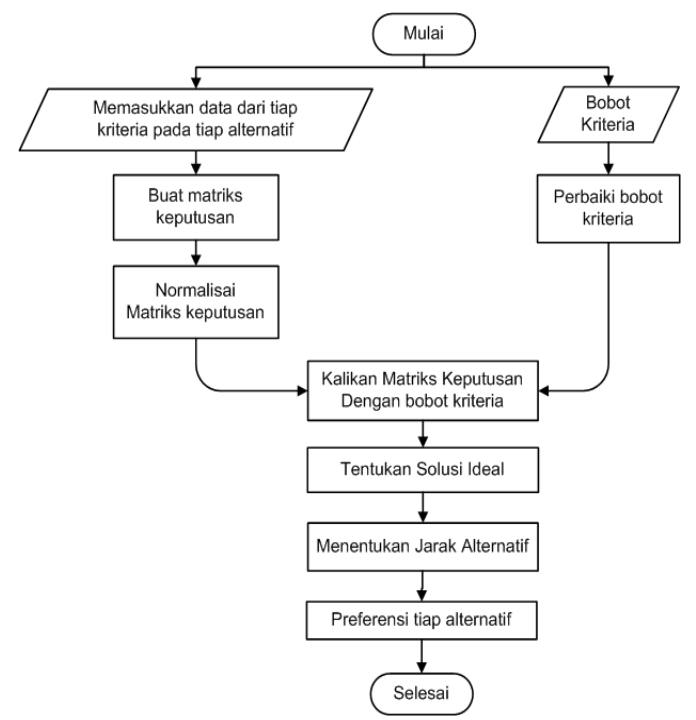

Gbr. 2 Flowchart AlgoritmaTOPSIS

\section{Metode Pengujian}

Pengujian dilakukan untuk mengurangi kesalahan dan memastikan keluaran yang dihasilkan sesuai dengan yang diinginkan. Salah satu caranya adalah dengan menerapkan confusion matrix sebagai model klarifikasi. Confusion matrix digunakan untuk memperoleh nilai precision, recall, dan accuracy.Nilai confusion matrix biasanya ditunjukkan 
dalam satuan persen (\%).Confusion matrix ditunjukkan pada Tabel I.

\begin{tabular}{|c|c|c|c|}
\hline \multirow[b]{4}{*}{$\begin{array}{l}\text { Actual } \\
\text { class }\end{array}$} & & \multicolumn{2}{|c|}{ Predicted class } \\
\hline & & CGT & NON CGT \\
\hline & CGT & $\begin{array}{c}\text { True Positive } \\
(T P)\end{array}$ & $\begin{array}{c}\text { False Negative } \\
(F N)\end{array}$ \\
\hline & $\begin{array}{l}\text { NON } \\
\text { CGT }\end{array}$ & $\begin{array}{l}\text { False Positive } \\
\text { (FP) }\end{array}$ & $\begin{array}{c}\text { True Negative } \\
(T N)\end{array}$ \\
\hline
\end{tabular}

Rumusan masing-masing adalah sebagai berikut:

$$
\begin{aligned}
& \text { Precision }=\mathrm{TP} /(\mathrm{TP}+\mathrm{FP}) \times 100 \% \\
& \text { Recall }=\mathrm{TP} /(\mathrm{TP}+\mathrm{FN}) \times 100 \% \\
& \text { Accuracy }=(\mathrm{TP}+\mathrm{TN}) / \text { Total Sampel } \mathrm{x} \\
& 100 \% \text { (14) }
\end{aligned}
$$

\section{Penetapan Variabel}

Berdasarkan permasalahan dan tinjauan pustaka yang relevan dengan topik penelitian, variabel yang akandigunakan secara garis besar meliputi data pribadi, nilai orientasi pelayan, nilai integritas, nilai komitmnen, nilai disiplin, nilai kerjasama, nilai kepemimpinan dan nilai prilaku kerja.
Dengan pembagian bobot $20 \%$ nilai orientasi pelayan, $20 \%$ nilai integritas, $15 \%$ nilai disiplin, $15 \%$ nilai kerjasama, $15 \%$ nilai kepemimpinan dan $15 \%$ nilai perilaku kerja.

\section{PENGUJIAN DAN PEMBAHASAN}

\section{Persiapan Data}

Pada tahap pengujian ini, data yang digunakan sudah dibersihkan dan ditransformasikan dalam bentuk kategori. Data yang digunakan adalah data sample dan dummy. Jumlah data yang digunakan adalah terdiri dari 300 field data.

\section{Pengujian}

Pengujian ini bertujuan untuk mengetahui unjuk kerja Promethee dalam melakukan perangkingan. Selain itu, pengujian juga dilakukan pada TOPSIS untuk mengetahui kinerja dan perbandingan performa.Pada uji coba ini, perbandingan performa diperoleh dengan mengambil nilai dari Tabel I confusion matrix untuk menghitung nilai precision, recall, dan accuracy dari hasil 
pengujian. Berikut hasil pengujian dari beberapa percobaan:

1) Metode Promethee

Pada metode Promethee, proses yang dilakukan adalah menentukan nilai entering flow, leaving flow dan net flow sehingga menghasilkan perankingan.Hasil dari perangkingan dapat dilihat pada Tabel II.

TABEL II

HASIL RANGKING PROMETHEE

\begin{tabular}{cccc}
\hline \hline No & NIP & Net Flow & Keputusan Promethee \\
\hline 1 & 195912151981032000 & 158.70358 & CGT \\
2 & 195906271986031000 & 152.71050 & CGT \\
3 & 195910301986092000 & 148.72808 & CGT \\
4 & 195912281992031000 & 147.07658 & CGT \\
5 & 196002161986031000 & 134.02750 & CGT \\
6 & 195907051986032000 & 132.42000 & CGT \\
7 & 196001191980032000 & 124.37375 & CGT \\
8 & 195907051987032000 & 123.55667 & CGT
\end{tabular}

Dari table II dapat dilihat semakin besar nilai dari net flow maka semakin tinggi posisi rangking dan prometheeakan merangking Nip yang memiliki nilai net flow yang tinggi sebagai calon guru teladan.

\section{2) Metode TOPSIS}

Pada percobaan ini, dilakukan proses metode TOPSIS sesuai dengan alur flowchart pada Gambar 2. Hasil yang diperoleh berupa ranking sebagaimana diberikan pada Tabel III. Tabel III menjelaskan bahwa dalam algoritma TOPSIS nilai yang di jadikan acuan untuk melakukan perangkingan adalah nilai prefensi.Yang dihasilkan dari (11).Semakin besar nilai prefernsi maka semakin tinggi pula posisi rangking.

TABEL III

HASIL RANGKING TOPSIS

\begin{tabular}{cccc}
\hline \hline No & NIP & Nilai Preferensi & Keputusan Topsis \\
\hline 1 & 195910301986092000 & 0.87599 & CGT \\
2 & 195512131983032000 & 0.86771 & CGT \\
3 & 195906271986031000 & 0.86714 & CGT \\
4 & 195912281992031000 & 0.85729 & CGT \\
5 & 195407311981022000 & 0.85562 & CGT \\
6 & 195510261979121000 & 0.85554 & CGT \\
7 & 195702081986031000 & 0.85477 & CGT \\
8 & 195907051987032000 & 0.85414 & CGT \\
\hline
\end{tabular}




\section{Analisis}

Pengujian yang dilakukan dengan menggunakan data uji $100 \%$ yaitu jumlah data 300 field dengan menggunakan algoritma TOPSIS dan Promethee. Uji coba ini bertujuan membandingkan performa algoritma Promethee dengan algoritma TOPSIS sebagai sistem pendukung keputusan proses seleksi guru teladan.Perbandingan didasarkan pada precision, recall, accuracy, dan waktu uji.Hal tersebut dapat dilihat pada Tabel IV.

TABEL IV.

ANALISIS KINERJA PROMETHEE DAN TOPSIS

\begin{tabular}{lllllll}
\hline \hline \multicolumn{5}{c}{ Algoritma Promethee } \\
\hline Data & Jenis & $\mathbf{P}(\%)$ & $\mathbf{R}(\%)$ & A (\%) & Waktu (ms) & Data Testing \\
\hline $\mathbf{1}$ & Guru & 91 & 54 & 88 & 467 & 300 \\
\hline \multicolumn{6}{c}{ Algoritma TOPSIS } \\
\hline Data & Jenis & $\mathbf{P}(\%)$ & $\mathbf{R}(\%)$ & A $(\%)$ & Waktu (ms) & Data Testing \\
\hline $\mathbf{1}$ & Guru & 90 & 74 & 94 & 26 & 300 \\
\hline $\mathrm{P}=$ Precision, $\mathrm{R}=$ Recall, $\mathrm{A}=$ Accuracy, & ms = milisecond
\end{tabular}

Tabel IV menjelaskan bahwa algoritma Promethee memiliki nilai precision, recall, dan accuracy sebesar $91 \%, 54 \%$, dan $88 \%$, sedangkan algoritma TOPSIS sebesar 90\%, 74\%, dan 94\%. Sedangkan berdasarkan waktu, algoritma Promethee lebih lambat yaitu $467 \mathrm{~ms}$ dari pada algoritma TOPSIS yang memiliki kecepatan 26 ms. Hasil pengujian diperjelas dengan grafik pada Gambar 3 yang menggambarkan perbandingan nilai dari precision, recall, dan accuracy.

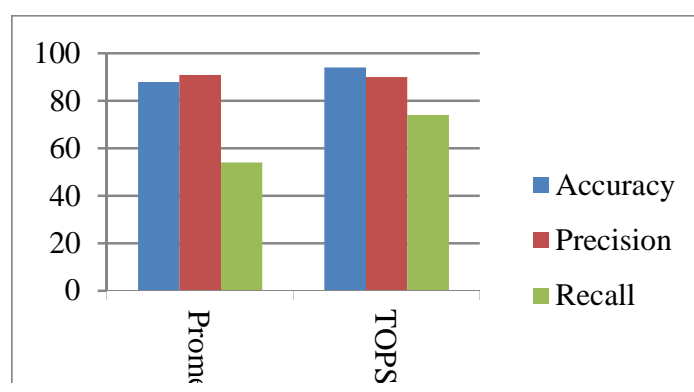

Berdasarkan hasil pengujian dapat diambil kesimpulan bahwa algoritma TOPSIS memiliki nilai unjuk kerja yang lebih baik dari pada algoritma Promethee, baik dalam hal kecepatan waktu maupun persentase akurasi dan recall. Algoritma Promethee hanya memiliki keunggulan pada persentase presisi.Hal ini dikarenakan algoritma Promethee melakukan perbandingan satu persatu untuk setiap kriteria yang diberikan dan membandingkan nilai yang diperoleh dengan nilai tengah (median) yang dijadikan acuan.

\section{KESIMPULAN}

Dari hasil penelitian yang telah dilakukan dapat disimpulkan bahwa:

1. Perhitungan algoritma Promethee lebih kompleks dibandingkan algoritma 
TOPSIS karena Promethee melakukan perbandingan tiap atribut satu persatu.

2. Hasil pengujian menunjukkan bahwa perbedaan data yang digunakan menampilkan hasil yang berbeda antara kedua algoritma.

3. Hasil implementasi yang diujikan pada pemilihan calon guru teladan menghasilkan nilai precision, recall, accuracy dan error rate untuk Promethee masing-masing 91\%, 54\%, $88 \%$ dan $11 \%$. Sedangkan untuk TOPSIS menghasilkan nilai precision, recall, accuracy dan error rate masingmasing 90\%, 94\%, $74 \%$ dan $5 \%$. Sehingga, dalam penelitian ini penggunaan algoritma TOPSIS memiliki unjuk kerja yang lebih baik daripada algoritma Promethee.Karena algoritma TOPSIS memliki nilai persentase accuracy yang jauh lebih tinggi dari pada algoritma Promethee.

\section{DAFTAR PUSTAKA}

Kusumadewi, S., Hartati, S., Harjoko, A., dan Wardoyo, R. 200. Fuzzy MultiAttribute Decision Making (FUZZYMADM). Yogyakarta: Graha Ilmu.

J. P. Brans dan Ph. Vincke. 1986. A Preference Ranking Organisation Method: (The PROMETHEE Method for Multiple Criteria Decision-Making). Management Science, Vol. 31, No. 6 (Jun., 1985), pp. 647-656.
Novaliendry. 2009. Sistem Pendukung Keputusan Menggunakan Promethee. Universitas Negeri Padang.

Sprague, Ralph H., Watson, Hugh J, 1989. Decision Support System - Putting Theory Into Practice.Prentice Hall.

Kahraman, C. 2008. Fuzzy Multi Criteria Decision Making. Springer. Istanbul.

Gorunescu, F. 2011. Data Mining Concept Model and Techniques. Springer. Berlin. 